\title{
The Contribution of Diaspora on Household Poverty Alleviation: Zanzibar Urban West Region
}

\author{
Juma Said Ali (Bahogo)
}

\author{
Centre for Foreign Relations, Dar es Salaam, Tanzania. P.O.BOX, 2101, Zanzibar
}

\begin{abstract}
The main objective of this study was to examine the contributions of Diaspora on household poverty alleviation in Unguja Urban West Region Zanzibar. The results indicate that the people living in Diaspora contribute greatly to their household members in terms of improving their income. The Diaspora brought to the home population between TZS 1, 000,000 up to TZS 5,000,000 which mark 64\% of the income. About $44 \%$ of the total income brought by Diaspora is coming in the holy month of Ramadan. While $33.3 \%$ of the income is coming in the holydays and only $23 \%$ of the funds are coming in other months when needed by household members. Furthermore, the results show the positive effect on the contribution of Diaspora on supporting social services to the household members. Whereas $59 \%$ of the income brought for social services from the Diaspora is being used for education development, $26 \%$ is being used for the development of health and $15 \%$ is for other services like paying for electricity and water bills. Zanzibaris in Diaspora are increasingly making contributions to the establishment of investments. The statistics on investment by Diaspora show that investment in car ranks top $(28.2 \%)$ followed by investment in running shops (18\%) building schools (15.3\%), establishing stationary, $(15.3 \%)$ opening dispensary $(13 \%)$ and $10.2 \%$ are invested in other areas. General findings reveal that members living in Diaspora established Information Technology Centre and Education Centres in Unguja Ukuu which help the member of households and other people in the society in Unguja. The study conclude that Diaspora is important in the poverty reduction to the extent that their contribution in improving peoples income, provision of social services like education and health services are the major indicators in the improvement of living standards to the people. It is recommended therefore that the Zanzibar government should increasingly recognize the contribution they make in poverty alleviation and economic development of their home country and has to take some positive steps to engage in Diaspora. Also the government is recommended to know where Diaspora lives, their numbers, level of education and their occupation the case that will be easily to utilize them in their country of origin
\end{abstract}

Tel:+2255777-889555,E-mail: jumasali2011@gmail.com

\section{Introduction}

The word "Diaspora" is undoubtedly one of the most widely used terms these days. It commonly appears in migration-related publications and articles. But what does "Diaspora" really mean Diaspora comes from the Greek verb Speiro, meaning' to 'sow', and the preposition; 'dia', meaning over (Blackwell Encyclopedia of sociology). Based on this etymology, Diaspora refers to the sowing over, scattering, or dispersion of a group of people mainly in terms of migration.

Its classic definition refers to a group of people or an ethnic population living outside of their home country in exile due to forced displacement. The above explanation means that there are those group of people leave their countries due to number of reasons, some of them is due to the law of their original countries forced them to disperse in other country for a while, and there are those who are legally and illegal migrant.

According to Zaleza (2005), diaspora refers to simultaneously to a process, connection, a space and a discourse; the continuous processes by which a Diaspora is made, unmade, and remade; the changing conditions in which it lives and expresses itself the places where it is molded and imagined; and the continuous ways in which it is studied and discussed "Based on what he regards on nine common features of diasporas Robin Cohen distinguishes between the" Victim diasporas" Africans and Armenians," labor diasporas" Indians," imperial diasporas" British, "trade diasporas" Chinese and Lebanese, and "cultural diasporas" the Caribbean Kim Butler, a historian of African Diaspora in Brazil, suggests another scheme as for diasporan study divided into five dimensions; reasons for and conditions of the dispersions dispersal; relationship with homeland, relationship with host lands; relationships with Diaspora groups; and comparative study of different diasporas. The term Diaspora has historically been associated with the notion of dispersion of an ethnic population outside its traditional homeland. It is linked with the notion of forced displacement, victimization, or alienation Cohen (1997). According to Gumla (2012), Zanzibar has long history of migrant from revolution period in 1964, where by many people left the country to find better place to save their lives. The most kind of people who left the country ware educated who were forced to live in exile, also many young girls aged from fifteen to thirty escaped due to the fear of being married by Africans in that case parents had to send their girls abroad due to 
forced marriage. Also other Zanzibaris left due to farming activities where by people were given large plots which could not able to finish. During that period the main transportation vessels used were dhow and ngalawa (ibid). According to Ghasany (2010), during the Zanzibar revolution hundreds of people left the country where by most of them they went to Dubai, some managed to get the ship in Zanzibar some they left through Mombasa sea port by Karfuyes ship when they riched Dubai were welcomed by King, Sheikh Rashid bin Said AlMaktoum, Also Zanzibar Association was established in Dubai in 13 July 1964 and signed by Mr Ali Masoud Thani. Although there are good number of Zanzibaris living outside their country as Diaspora, there is no study that has been indicated to examine their contribution on household poverty alleviation.

\subsection{Research Problem.}

It is a fact that many Zanzibaris have migrated to other countries as diaspora. However, there is no study that has been done to examine the contribution of Diaspora to household poverty alleviation in Zanzibar. Therefore this research aims at examining the contribution of Zanzibaris in the poverty alleviation, of their household members.

\subsection{Method}

The study used survey design this is due to the nature of study. This method was capable of yielding information, describing the existing perceptions, views, attitudes, behavior or values of individuals within a community. Furthermore, this method was very useful to the extent that the researcher could collect information by interviewing and administering a questionnaire to a sample of individuals.

\section{Results}

Majority of respondents when they were interview whether they received money or no, $90 \%$ of the response were yes, which means that they received money from their relatives living in Diaspora. Only $10 \%$ they claimed to have not received money from their relatives. The results from this study shows that $25(64.1 \%)$ of the respondents reported to have received money from Diaspora between TZS 0 up to TZS 1,000,000 in the past one year and $11(28.2 \%)$ received in the range of TZS 1,000,000 up to TZS 5,000,000 and only $3(8 \%)$ had received money in the range of TZS 5,000,001 and above, hence indicates good image on the contribution of Diaspora on improving household income.

Table: 1 Amount of Money Received from the Diaspora members

\begin{tabular}{|l|c|c|}
\hline \multicolumn{1}{|c|}{ Description } & Frequency & Percent \\
\hline $0-1,000,000$ & 25 & 64.1 \\
\hline $1,000,000-5,000,000$ & 11 & 28.2 \\
\hline $5,000,001$ and above & 3 & 8 \\
\hline Total & 39 & 100 \\
\hline
\end{tabular}

\section{Source: Survey Results, 2012}

Table 2 below depicts that about 17(44\%) of the respondents received money during the Holy month, while 13 $(33.3 \%)$ of respondents reported that they normally receive money during the holydays. Nine [9 (23.0\%)] of respondents claimed money to be received in other period. The trend implies that more money are needed during the holy month and holy days. This is due to the fact that, many people in Zanzibar during these period their expenditure increased at a high level as compared to other periods, since they spent more money in buying foods and other needs during the holy month whereby at this time price of foods rise high so money are hardly needed, the same during the holyday where member of the households need them to buy new clothes charity share ring and other ornaments for their family as a sign of celebrating after breaking their fast.

Table: 2 Period of Receiving Money from Diaspora

\begin{tabular}{|l|c|c|}
\hline \multicolumn{1}{|c|}{ Description } & Prequency & Percent \\
\hline Holy month & 17 & 34 \\
\hline Holyday & 13 & 23.3 \\
\hline Others & 9 & 100 \\
\hline Total & 39 & \\
\hline
\end{tabular}

\section{Source Survey Results, 2012}

Figure 3 below, shows that the main use of remittances by recipients is for home consumption $14(36 \%)$ of respondents reported to buy foods and 11 (28.2\%) respondents reported to use for rent, $10(26 \%)$ of the respondents most of the funds received from their members were used for buying clothes and only $4(10.2 \%)$ of respondents reported to use for other needs. The trend indicate that more money used for buying foods and this is 
obvious for most of the people in Zanzibar, to make life easy when they get money they buy varieties of food and stored them for the long term consumption.

Table: 3. The Uses of Money Received from Diaspora

\begin{tabular}{|l|c|c|}
\hline \multicolumn{1}{|c|}{ Description } & Frequency & Percent \\
\hline Food & 14 & 36 \\
\hline Shelter & 11 & 28.2 \\
\hline Clothes & 10 & 26 \\
\hline Others & 4 & 10.2 \\
\hline Total & 39 & 100 \\
\hline
\end{tabular}

\section{Source Survey Results, 2012}

\subsection{Contribution of Diaspora in Provision of Household Social Services}

Many respondents when they were interviewed responded "yes" that they received services from their member living in Diaspora, and the received services have a great impact in improving their living standards. Table 4. 6 reveals that 23 respondents $(59 \%)$ reported that members living in Diaspora tend to provide highly for education services and $10(26 \%)$ claimed to benefit health services and only $6(15 \%)$ of respondents reported to get for other services.

Table: 4. Services provided from the Member living in Diaspora

\begin{tabular}{|l|c|c|}
\hline \multicolumn{1}{|c|}{ Description } & Frequency & Percent \\
\hline Education & 23 & 59 \\
\hline Health & 10 & 26 \\
\hline Others & 6 & 15 \\
\hline Total & 39 & 100 \\
\hline
\end{tabular}

Source Survey Results, 2012

\subsection{Investments established by Diaspora to benefit household members}

The table 5 below shows that $11(28.2 \%)$ reported that cars are the most invested in for by member living in Diaspora. $7(18 \%)$ were reported to be investing in shops, school account $6(15.3 \%)$ and another $6(15.3 \%)$ investing in stationeries, $5(13 \%)$ of the respondents reported investment in dispensaries and only $4(10.2 \%)$ of the respondents reported to be investing in other areas like building houses and buying farms for agriculture.

Table: 5. Investment made by the Household Member living in Diaspora

\begin{tabular}{|l|c|c|}
\hline \multicolumn{1}{|c|}{ Description } & Frequency & Percent \\
\hline Car & 11 & 28.2 \\
\hline Shop & 7 & 18 \\
\hline School & 6 & 15.3 \\
\hline Stationary & 6 & 15.3 \\
\hline Dispensary & 5 & 13 \\
\hline Others & 4 & 10.2 \\
\hline Total & 39 & 100 \\
\hline & & \\
\hline
\end{tabular}

\section{Source Survey Results, 2012}

The researcher conducted an interview to some officials from the department of Diaspora at Zanzibar State House, and the following were the evidence as reported by respondents. From the respondent experience as an official reported that, in the past one year Diaspora contributed total of $£ 36,000$ equal to the total of TZS 7,254,000. Normally, every Holy month (like Ramadan) when people they make fasting Diaspora send more money to their household members the same during the holyday when many are more useful. From another respondent also it was revealed that, Diaspora contributed to their household by providing money to members of their family. Results from interview shows that member living in Diaspora actively invested in ICT Centre commonly called (Tameta) and Education Centre in Unguja Ukuu which charges low costs, and others bring furniture. In general, Diaspora invest in their home countries and these investments help to improve the lives of 
their relatives in many ways, also it was reported that there were three families who sent their children to study abroad in high schools and one family built family dispensary and many people benefits from their services.

\section{Conclusion and Recommendations}

Zanzibaris in the Diaspora contribute in fighting against poverty in the household at the Urban West region of Unguja and represent a vital resource that need to be fully tapped and encouraged to participate in the development of their country of origin. Zanzibar government therefore should increasingly recognize the contribution they make in poverty alleviation and economic development of their home country and has to take some positive steps to engage the Diaspora. Zanzibar government needs to work on setting up a data collection mechanism and building up a database for her nationals in the Diaspora; this will help in ascertaining the actual number of nationals in the Diaspora, their location, occupation and their skills. The data collection needs to involve all stakeholders both government and private. Regular and efficient data collected will help provide vital information for planning and policy making. Lessons and ideas can be drawn from other countries like India, China and Kenya that have built-up impressive models from their Diaspora engagement strategies. Improvements and adjustment can then be done to fit within locally available resources in order to address the particular issues faced Zanzibaris in Diaspora. Zanzibaris in the Diaspora have good will to contribute to the development of Zanzibar through direct investments, technology transfer, trade and remittances. Zanzibar government needs to support them obtain legal status in their host countries and also pass a law allowing nationals in the Diaspora to hold duo-citizenship. Zanzibar government needs to put in place appropriate economic policies and reforms that will help reduce the cost of sending remittances from nationals in the Diaspora, this may include encouraging and licensing more private financial institutions to provide remittances services, increase competition and hence lowering of costs, also will encourage more people to send remittances through formal channels. Currently a large amount of remittances from the Diaspora goes unrecorded because of the preference of sending through informal channels, this distorts data collection and makes it for policy makers to plan appropriately for better management of remittances. Lastly, Zanzibar government in partnership with Diaspora Associations and the host countries need to establish a migrant welfare fund to help protect and empower migrants. These funds will be helpful in providing assistance to migrants like providing health care, repatriation in case of death or natural disasters.

\section{References}

Daily News, Wed, May 2, 2012, Revised at 03:20 am

Ghassany, H. (2010). Goodbye Colonialism, Goodbye Freedom! Zanzibar and the Afrabia Revolution.

Gumla. A, (2012). Conversation Undertaken by Researcher and Expert and Historicals person on the Zanzibar Revolution of 1964

Zaleza, P. (2005). African Diaspora New Dictionary of History of Ideas.2005, Retrieved

March 19, 2012 from Encyclopedia.com: $\quad \underline{w w w . e n c y c l o p e d i a . c o m / d o c ~}$ 
The IISTE is a pioneer in the Open-Access hosting service and academic event management. The aim of the firm is Accelerating Global Knowledge Sharing.

More information about the firm can be found on the homepage:

http://www.iiste.org

\section{CALL FOR JOURNAL PAPERS}

There are more than 30 peer-reviewed academic journals hosted under the hosting platform.

Prospective authors of journals can find the submission instruction on the following page: http://www.iiste.org/journals/ All the journals articles are available online to the readers all over the world without financial, legal, or technical barriers other than those inseparable from gaining access to the internet itself. Paper version of the journals is also available upon request of readers and authors.

\section{MORE RESOURCES}

Book publication information: http://www.iiste.org/book/

Recent conferences: http://www.iiste.org/conference/

\section{IISTE Knowledge Sharing Partners}

EBSCO, Index Copernicus, Ulrich's Periodicals Directory, JournalTOCS, PKP Open Archives Harvester, Bielefeld Academic Search Engine, Elektronische Zeitschriftenbibliothek EZB, Open J-Gate, OCLC WorldCat, Universe Digtial Library, NewJour, Google Scholar

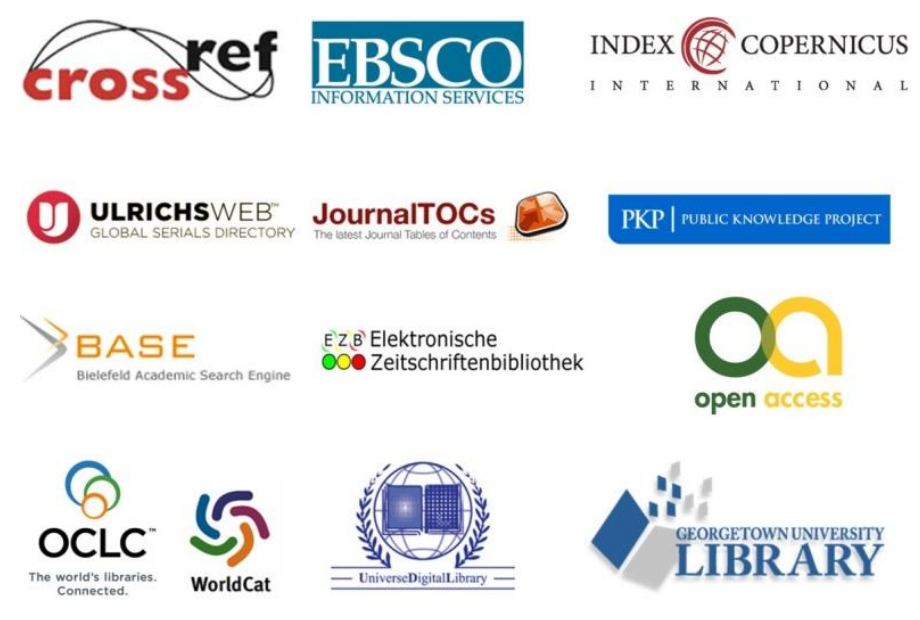

